\title{
ІСТОРИЧНІ ВИТОКИ УКРАЇНСЬКОГО НАЦІОНАЛЬНОГО СВІТОГЛЯДУ
}

\section{В.Ф. Капіца, А.П. Звенігородська}

Етнокультурні передумови становлення світогляду українського народу, на наш погляд, полягають в розвитку такої «філософії духу», в якій синтез природного і надприродного, органічного й інтелектуального представлений більш на сенсорно-почуттєвому підгрунті, ніж на раціоналістичному, більш прямо і безпосередньо, ніж розумово і розсудливо, більш споглядально та інтуїтивно, феноменологічно, ніж абстрактно-логічно. Такій філософії притаманний «живий зв'язок» духу і серця (кардіософія), первинність «задушевної людини», а не «абстрактного» чи «абсолютного» духу. Національна духовність $\epsilon$ безпосередньо «інтегруючим духом» у виявленні різних форм людської духовності, в живому «духовному синтезі» загальнолюдських родових початків, розуму і серця, буття і пізнання, що й становить, як ми вважаємо, основу національної ментальності [2, с. 105].

Актуальність даної розробки полягає в необхідності формування національного суспільного світогляду українців як єдиної нації, а на цій основі - створення сильної політичної державності. Тому за мету дослідження ставилося виявлення культурно-історичних витоків національного світогляду, яке формувалося на підгрунті давньої української культури. Як ми вважаємо, подібні погляди мають велике практичне значення для національного відродження під час формування в Україні гуманізованої суспільної системи європейського зразка, а також у практичному вихованні української молоді.

Новий «континуальний вимір» національної свідомості задає максимально широкі параметри іiі розвитку і прирощення аж до рівня «глобальної свідомості», релевантної українському народові як світо-

Актуальні проблеми духовності 
вої нації. Подібних вимірів-рівнів три. Це загально-методологічний рівень, в його історико-філософському аспекті (вимір світоглядно-методологічного бачення процесів творення національної свідомості); вимір української національної філософської думки в аспекті антропогенної філософії; етнорегіональний вимір «практичної філософії» (комунікативної, когнітивної та інших різновидів), включаючи протофілософський вимір прадавнього світобачення наших предків в системі національної етнокультури. Підняття з етнорегіонального рівня на виміри національні і транснаціональні, міжнародні і глобальні можна розглядати як «історичний шанс» України в $\dddot{1}$ сучасному Відродженні і Відтворенні. Але практична реалізація подібного шансу можлива (i може початись) тільки з історичних глибин і першовитоків формування прадавньої української етнокультури і світогляду [2, с. 40-43,76-81].

Сучасні етнологічні дослідження все більше звертаються до «історичної етнології» і формулюють на ㄲï засадах «адаптаційно-діяльнісний» підхід до культури. При цьому фіксується «криза психологічного підходу до етнології і перевага віддається «когнітивній антропологіi», яка дозволяє створити «етнічну картину світу» [5, с. 153-154]. Це значно наближає класичну етнологію до антропогенної філософії і осмислення етногенезу на основі історико-філософської методології.

Філософсько-методологічне й історико-філософське підгрунтя при вивченні історичних етнопроцесів національного культурогенезу потрібніше тим, що історико-етнологічні дослідження виходять на сучасність і деякі великі регіони України починають себе етнічно ідентифікувати через виникнення «регіональної самосвідомості», «самосвідомості етнотериторіальної спільноти». Про можливість «регіонального різновиду» у випадку досягнення Україною певного рівня в національній розбудові суспільства в новітній історії та про кардинальну зміну «ролі України в Новітній історії» в статусі «модерної України», «самосвідому політичну і культурну спільноту» говорив видатний український культуролог І. Лисяк-Рудницький, що чітко визначав ключову роль української нації в духовному творенні східноєвропейської культури [4, с. 524-541].

«Регіональні різновиди» до середини 90-х років минулого сторіччя пов'язувалися з економічним аспектом формування територіальновиробничих комплексів. Тобто з виникненням «економічної свідомості» або за західною термінологією - «індустріальної свідомості» (а згодом i «постіндустріальної свідомості» в «інформаційних суспільствах» техногенного типу). Але вже наприкінці 90-х років, з поглибленням процесів соціально-економічної трансформації в Україні, тен- 
денція до «регіоналізації» більше розглядаються як «соціально-політичний феномен», самостійно діючий «етнонаціональний фактор», що дуже впливає на формування загальнонаціональної суспільної свідомості. Етнорегіональні спільноти почали розглядатися як такі, що «дозріли» до усвідомлення потреб свого духовного соціально-економічного і політичного розвитку. Вони «відображаються в її інтересах та ідеалах, спонукаючи спільноту до дії, стають явищем соціальної дійсності». Виникає духовна інтеграція етнічної і національної свідомості, а 3 цим їх взаємна ідентифікація: «етнічна, національна свідомість (самосвідомість), здатна не тільки обумовлювати дії свого носія, а й викликати реакцію на себе з боку іншого соціального суб'єкта (етнічної спільноти, політичного інституту тощо)» [7, с. 46].

На початку XXI сторіччя приходить усвідомлення, що виникнення «етнорегіональної свідомості», що перетворюється на етнонаціональну свідомість», виходячи з індустріальної розвиненості України, пов'язана не тільки з економічними чинниками та соціально-політичною трансформацією суспільства, а й з «кризою індустріалізму» і необхідністю створення умов постіндустріального розвитку суспільства. I. Кононов вважає, що при такій «Кризі індустріалізму» починають усвідомлюватись міфи, щодо особливого промислового значення індустріальних регіонів. Формується концепція етноідентифікації регіональних спільнот [3, с. 90-92]. Для того, щоб дати нове життя індустріальним регіонам, потрібне не створення «економічних» чи «ринкових міфів», а дійсний розвиток регіональної життєдіяльності, виходячи 3 ïх культурно-історичних потенціалів. Це потребує глибокого історикофілософського осмислення тих зрушень, що відбуваються у духовному житті етнорегіонів, в регіональній свідомості їх громадян, яка формує нові духовно-просторові виміри та цінності загальнонаціональної суспільної свідомості.

Тому один найважливіший філософсько-методологічний аспект первовитоків національного світогляду - це його етно-регіональний вимір. На цьому рівні формується «практична філософія», задіюються практично-моральні контексти первісного національного буття, будить історичну свідомість українського народу. Національний світогляд етно-регіонального рівня безпосередньо грунтувався на етно-національному усвідомленні макроетнічної ідентичності українського народу, що напрямки вела до креативної самореалізації українського макроетносу в націю, в єдине і цілісне національне суспільство. Цей процес йшов від багатьох стародавніх культурно-регіональних центрів, які потребували об'єднання, згідно єдиного макропринципу етно-територіального 
буття українського суперетносу. Це буття здійснювалося в інтегруванні життєдіяльності нації на основі макропринципу єдиної історичної культури впродовж різноплинного, але центровекторного просторового часу національного становлення.

Високий рівень розвитку етносу етнонаціональної свідомості досягається, за Дж. Маккейем і Ф. Льюісом, коли фіксується «максимальна етнічність» історичної спільноти, що об'єднує людей, які тоді беруть активну участь в забезпеченні своїх політичних економічних, соціальних та інших інтересів, і вони можуть створювати «великі суспільства». За відсутністю відповідної «етнічності», яка характеризується низькою етнічною обізнаністю» людська спільнота залишлається на стадії «мінімуму етнічності» або ж попадає в розряд «маргінальних етносів» чи «етнічних сиріт», які не мають тісних зв'язків з головним етнонаціональним угрупованням $[6$, c. $35-36]$. «Етнічна основа української спільноти», виходячи з цього, визначається як така, що сформувалась в «процесі етногенезу на теренах України, на грунті східнослав'янських племен» у значенні «історичної категорії людяності, наділеної характерними етнічними ознаками (європеїдний фізичний тип, своєрідна ментальність, певні усталені традиції, культура, побут, християнська релігія) і об'єднана в органічну цілісність територією, надродовими уявленнями та міфами про спільне походження і кров, усвідомлення своєї відокремленості з посеред сусідніх етноспільнот, що виражається в самоназві (українці)» 6, с.38]. Інші відзнаки: загальнолюдські якості (гуманізм, миролюбність, працелюбність), традиції національного самовизначення, ідеологія державництва, тенденції до інтеграції у світову спільноту, формування як політичної нації, забезпечення етно-культурних потреб». I дуже характерна відзнака - це відсутність політичних кордонів, коли географія етносів «збігається 3 ареалом розселення етнічних українців», а сама етнооснова «опосередковано впливає на світовий історичний процес». Звідціля і йде принципове значення етно-регіонального виміру національного світогляду, у всьому її культурно-історичному багатстві у значенні «центровертованої національної свідомості». Вона як духовна основа української суспільної свідомості дозволяє їй з мікрофілософського світоглядного рівня піднятись на макрорівень загальнонаціональної макросвідомості, духовно-практичної свідомості антропогенної гносеології.

Таким чином, національна свідомість, розглянута в культурно-історичному контексті розвитку національної історико-філософської думки, стверджує себе як свідомість духовної суперпозиції, гіперсвідомість, що задіює себе на мікрорівні і на макрорівні, від інтровертова- 
ності (в напрямку духовного мікрокосмосу особистості) і до екстравертованості (в напрямку духовного мегакосмосу соціуму), а потім стверджується у духовній центроверсії-синтезі всіх позицій в єдину духовну суперпозицію від етносу до цивілізаційного і культурогенного зросту світової нації. За Н.Я. Данилевським, тут діє принаймні п'ять законів розвитку культурно-історичних типів цивілізації як «рухи їх розвитку» від етнокультури до «державного існування» і створення свого універсального «культурно-історичного типу» цивілізації. «Хід розвитку подібних цивілізацій більш всього уподібнюється тим одноплідним рослинам, у яких період зросту буває невизначено тривалий, але період цвітіння і родючості відносно коротким, виснажує раз і назавжди їх життєву силу» [1, с.91-92]. «Цвітіння» української духовності історично відбулося кілька разів, і вона немов би «раз і назавжди» відходила у небуття, але національна духовна свідомість підіймалася знову і знову на все більш високий світоглядний рівень. Сучасний процес національного Відродження, в повній мірі, базується на цьому культурноісторичному підгрунті зі ствердженням яскравого національного світогляду на основі європейської і світової культури.

\section{1 Бібліографія}

[1] Данилевский Н.Я. Россия и Европа. - М.: Книга, 1991.

[2] Kaniua B.Ф. Українська національна свідомість.-Кривий Ріг: Мінерал, 2005.

[3] Кононов И. Донбасс: этническая характеристика региона // Coциология: теория, методы, маркетинг, 2003. - С.90-92.

[4] Лислк-Рудницький I. Воля України в Новітній історії // Історія філософії. - К.: Либідь, 1993.

[5] Лурве С.В. Историческая этнология.-М., 2000.

[6] Мала енциклопедія етнодержавознавства. - К.: Генеза, 1996.

[7] Недолішній П.І. Розбудова нової системи врядування в Україні. Етнонаціональний аспект. - К.: Істро-Принт, 1999. 